Special Section : Rocky Plateaus

Research Paper

\title{
Lateritic Plateaus in the Northern Western Ghats, India; a Review of Bauxite Mining Restoration Practices
}

\author{
C. J. Thorpe $e^{1}$ and Aparna Watve ${ }^{2}$
}

\author{
1 : School of Biological Sciences, University of Plymouth, Plymouth, Devon, PL4 8AA, UK \\ Email : Christopher.thorpe-dixon@plymouth.ac.uk \\ 2 : Tata Institute of Social Sciences, Tuljapur, Osmanabad Dt., Maharashtra, India \\ Email : aparnawatve1@gmail.com
}

\begin{abstract}
The northern Western Ghats are characterised by plateaus and hilltop carapaces formed from ferricretes rich in aluminium ore. Ferricretes in Western Ghats are home to a high number of endemic species, many with extremely limited distribution. The heterogeneity of microhabitats on ferricretes supports a great diversity of plant and animal communities. With little overburden and a high percentage of recoverable metals they are targeted for mining which leads to removal of all soil, vegetation and microhabitats. Vegetation and faunal diversity of unmined sites from Kolhapur district were studied providing reference data used to discuss restoration efforts on two mined sites in the region. Restoration efforts have faced ecological and legal hurdles. The international literature for the restoration of bauxite mines fails to demonstrate any successful model to return the species assemblage to a pre-mining profile.

Restoration practices fail to adequately replicate microhabitat heterogeneity; often restoring sites to a different ecosystem from the original. The present mining policies do not take cognizance of the special nature of plateau habitats, ecology or the ecosystem functions they provide. We suggest a moratorium on mining of the high level lateritic plateaus in Western Maharashtra is justified until the biodiversity value and ecosystem services of the sites are fully understood and can be weighed against the economic gains from mining.
\end{abstract}

\section{Introduction}

Mining for fossil fuels, metals and minerals is essential for human society (Azapagic, 2004) and that demand has increased since industrialization. It places a pressure on the legislature to prioritise the values society places on access to materials without necessarily fully assessing or valuing the environmental costs of that access (Hilson and Basu, 2003; Laurence, 2011). Environmental Impact Assessment (EIA) is mandatory for mining in India by the 1994 notification under the Environmental Protection Act (EPA, 1986). In an EIA, mitigation measures are proposed in an Environment Management Plan (EMP) to avoid or reduce environmental and social impacts (Paliwal, 2006). The EIA should iterate the expected impact on the environment, its biota and the ecosystem services they provide together with the proposed measures to remove, reduce or compensate for the detrimental effects of mining (Drayson and Thompson,
2013). The weaknesses in the EIA process and its' implementation in India (Paliwal, 2006) have led to poor mitigation of the impact of mining.

Mining causes irreversible changes to the landscape, the environment and ecosystem services available to rural communities. Iron-ore mining in Karnataka (Krishnaswamy et al., 2003) and in Goa were opposed by environmental and social activists and scientists for detrimental effects on environment and livelihoods. In the Western Ghats, mining is known to affect freshwater biodiversity (Molur, 2011), disrupt hydrological and sediment linkages (Krishnaswamy, et al., 2006) and reduce species richness and community assemblages in amphibians (Krishnamurthy, 2003). Impacts of mining in ecologically sensitive areas of India are summarized by Vagholikar and Moghe (2003). The sustainability of bauxite mining in the Western Ghats is questionable (Phillips 2012).

Bauxite is one of the important ores found in the 
state of Maharashtra and mining leases have been granted on lateritic plateaus since 1968 (Directorate of Geology and Mining, 2015). The Western Ghats-Sri Lanka Biodiversity Hotspot was established in 2000 (Myers et al., 2000). The Western Ghats are recognised as being one of the three most threatened biodiversity hotspots in the world (Cincotta et al., 2000). Ferricretes in the northern section of the Western Ghats (NWG) are recognised as fragile habitats with high levels of endemism. They are described by Bharucha (2010) as hotspecks- miniscule areas of species concentration, varying in size from five to a few hundred square meters falling within or far outside today's recognized hotspots where species packing of diverse groups, including many endemics is found. New bauxite mining proposals in Northern Western Ghats (NWG) have been strongly opposed due to their predicted negative impacts on environment and society. In response to the opposition, mining companies have undertaken model restoration efforts at some sites. It has been argued that present models of restoration can successfully mitigate environmental impacts of bauxite mining and hence permissions to operate new mines on lateritic plateaus should be granted. Decision making regarding environmental clearance (by the State Environmental Authority) or forest clearance for diversion of forest land for mining (by the State Forest Department) has become a long drawn out process as environmental, social and corporate interests clash repeatedly over mining applications in Northern Western Ghats.

The present review was undertaken to discuss issues in restoration of bauxite rich ferricretes in NWG of Maharashtra.

The specific objectives of our study were,

1. To document vegetation and select fauna from unmined ferricrete as reference sites.

2. To discuss ecological, social and legal aspects of restoration on mined ferricrete using information from the reference sites.

High altitude ferricrete sites from Kolhapur and Sindhudurg districts were chosen for the review.

\section{Materials and Methods}

\subsection{Study area}

The Western Ghats (WG) are a 1500km long range of hills with an erosional escarpment on their western edge. In the northern section the lateritic soils form wide, flat indurated platforms on hill crests and ridges between $15^{\circ} 60^{\prime}$ and $18^{\circ} 20^{\prime} \mathrm{N}$ and at $800-1400 \mathrm{~m}$ above mean sea level (ASL) (Widdowson and Cox 1996).
These indurated platforms are ferricretes, or "sadas" in Marathi. The ecology and biodiversity of the ferricretes in the NWG has been described by Porembski and Watve (2005), Lekhak and Yadav (2012) and Watve (2013). Unique floral and faunal elements on ferricretes were documented by Joshi and Janarthanam (2004); Giri and Bauer (2008); Bhattarai, et al. (2013); Rogers and Padhye (2014).

Ferricretes in the WG are between 6 and 30m thick (Goudie, 1973). Bauxite occurs as thick capping on basalt in the Kolhapur district (Balasubramaniam and Paropkari, 1975). According to recent estimates of Directorate of Geology and Mining (Govt. of India, 2014) 133.111 million tonnes of bauxite reserve are present in NWG of which ferricretes in Kolhapur district have 83.53 million tonnes. They have little overburden and are covered by herbaceous vegetation unlike most other ferricretes in the world, which have a soil overburden and forest cover. Some ferricretes in Kolhapur have been mined since 1968 and new mines are proposed in the region.

\subsection{Methodology}

In order to answer the questions, "Does mining change ferricrete biodiversity?" and "are current restoration practices adequate?" we analysed the steps in restoration and its documented outcomes from mined sites. Microhabitat diversity, plant communities and selected faunal groups were observed on two unmined sites (Masai and Zenda), which provide reference for comparing restoration efforts on mining sites at Kasarsada and Durgamanwad. Table 1 gives details of the sites where the observations were carried out.

Direct observations were used for both quantitative and qualitative data regarding the habitats. Plant communities in diverse microhabitats were documented on two sites, Zenda and Masai between 20052014 as a part of ongoing study of ferricretes in NWG.

The wide variety of possible measures of biodiversity has been discussed in the literature. Biological surrogates are representative taxa that are known to change in species composition and abundance reflecting a wider group of species. They can be used as measures of richness, endemism, rarity, and complementarily of taxonomic or functional groups that are presumed to be indicators of biodiversity patterns at large. Gaston and Blackburn (1995) divide surrogates into following groups : (i) the species richness of indicator groups (delimited on the basis of taxon or function); (ii) the levels of various environmental parameters (e.g. precipitation, primary 
Map 1. Mined and un-mined sites in elevation context with town locations for location referencing

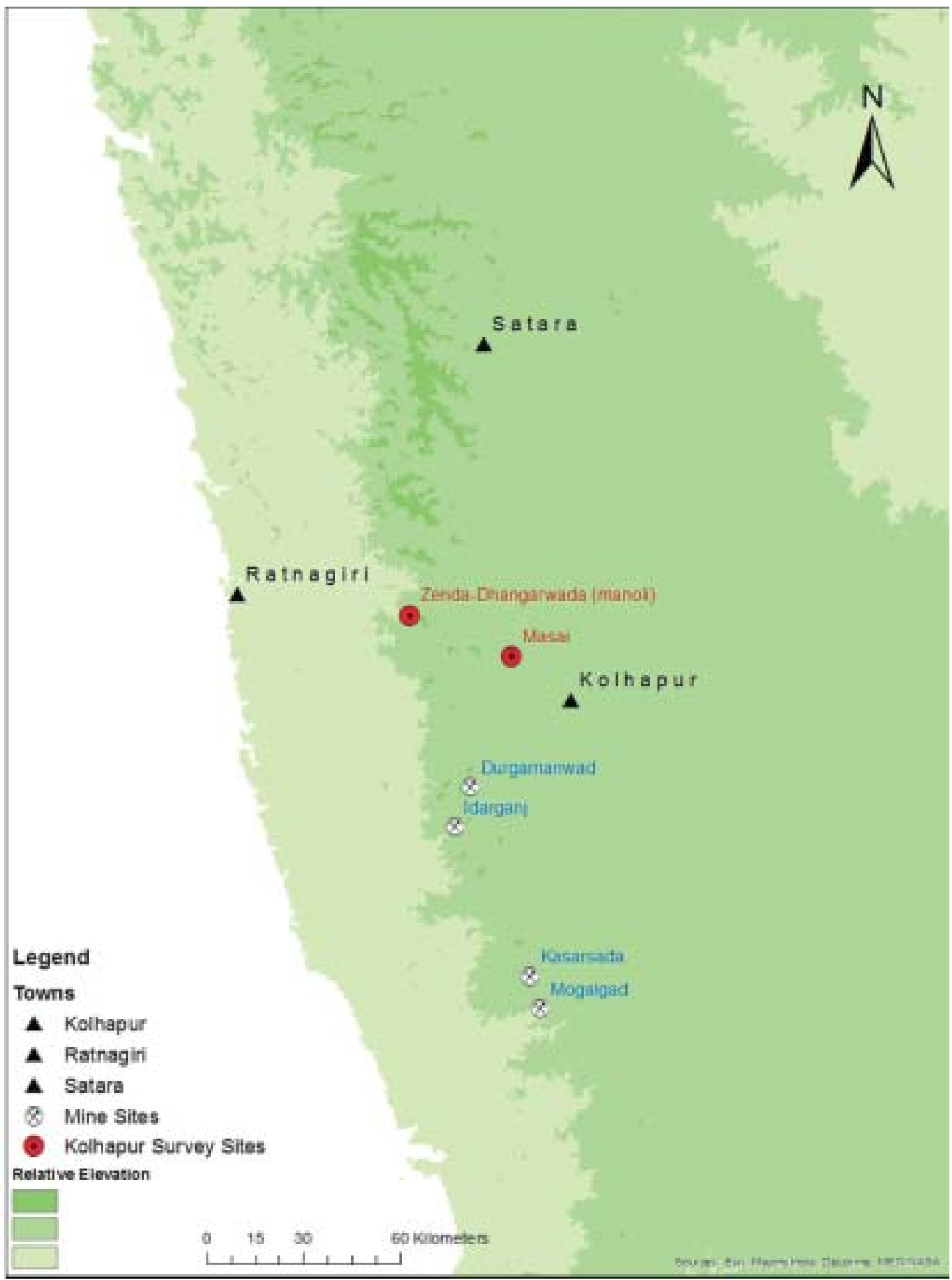


productivity, temperature, and positional correlates such as latitude, longitude and altitude); and (iii) the numbers of higher taxa (e.g. genera, tribes, families). For the present study, indicator groups of fauna were selected as surrogates for biodiversity pattern. Quantitative ecological observations of the selected faunal surrogates (amphibians, formicidae and aquatic coleopteran) were made on Zenda and Masai sites. Two of the mined sites, Kasarsada and Durgamanwad, where restoration has been carried out were visited for comparison. Observations were also made on Mogalgad and Idarganj sites.

Secondary information was collected from published papers and EIA, EMP and reports on mitigation and restoration projects of mined ferricretes. Policies and guidelines from the Ministry of Environment and Forest regarding mines are reviewed with special reference to bauxite mining in sensitive habitats within a global hotspot. Literature on mining and its impacts in India is limited. Kumar et al., (1995) conducted afforestation studies on laterites and mine dumps in Goa. Environmental and social impacts of bauxite mining are studied by Lad and Samant (2012). Kulkarni et al., (2013) have documented the technical restoration efforts by HINDALCO on two bauxite mining sites. Publications on bauxite mining in other countries were reviewed.

\section{Results}

Ferricretes in Kolhapur district are separated from each other by erosional valleys. The distance between the sites varies from $1 \mathrm{~km}$ linearly within a cluster to $10 \mathrm{kms}-50 \mathrm{kms}$ between the clusters. The plant communities on ferricretes are similar to each other but differ widely from those occupying surrounding weathered landscapes. Bhattarai et al., (2012) in their studies on Kas plateau in Satara have noted hydrology to be one of the key factors driving specialisation with $80 \%$ of the hydrogeomorphic species in the study area plateau tops. Scarcity of soil, extremes of climate, especially temperature and rainfall, influence vegetation on ferricretes where cryptogams and ephemerals are dominant. It has been shown that species richness of plateau communities is related to the range of available micro-habitats (Katwate, et al., 2013, Rahangdale and Rahangdale 2014).

\subsection{Species diversity and endemism on sites}

Endemic, habitat specialist species with limited distribution are reported from study sites. For example Eleocharis wadoodii S.R. Yadav et al. (Masai), Indigofera dalzellii Cooke, Impatiens lawii Hook. F. and Thomson
(Zenda, Idarganj). Unique assemblages of amphibians, aquatic invertebrates and formicidae, novel species, critically endangered and data deficient species are present on ferricretes.

The two selected sites Masai and Zenda ferricretes, have microhabitats characteristically seen on ferricretes. Sixty three species of annual herbs were seen on Masai plateau of which 18 are endemic to WG. Fifty four species of annual herbs were seen on Zenda plateau of which 28 are endemic to WG. Amphibians include Sphaerotheca dobsonii (Boulenger, 1882), Indotyphlus cf. battersbyi and the common Hoplobatrachus tigerinus (Daudin, 1803) on Masai and Indirana cf. beddomii and Fejervarya spp. on Zenda. Ants (Formicidae) species recorded on Masai and Zenda included Myrmicinae Crematogaster subnuda, C.rothneyi and C.dohrnii; Camponotus irritans; Myrmicinae Monomorium four spp; Myrmicinae Pheidole two spp; Ponerinae Pachychondyla spp. Formicinae Polyrhachis three spp; The list is illustrative of the range of species, not exhaustive. The range of pool microhabitats enable a wide range of habitat specialists to co-exist. For example Dytiscidae Microdytes svensoni requires very shallow water, ideally slowly moving as found on the exposed rock areas of a ferricrete. It coexists along with Gyrinidae Orectochilus Patrus spp. that require deeper pools with a much longer hydroperiod.

\subsection{Description of Microhabitats and ecological functions}

A brief description of microhabitats seen on these two sites is given below. Ecological functions reported for the microhabitats are included in Table 2.

\subsubsection{Exposed rock surface}

All rock surfaces exposed for enough time are covered in a crytpogamic or Biological Soil Crust (BSC). On ferricretes they are comprised of a vegetative complex of cyanobacteria, cyanobacterial lichens and bryophytes. They provide basking areas for many reptiles.

\subsubsection{Loose and semi buried rocks}

Rocks comprising of the parent material, varying in size from less than $10 \mathrm{~mm}$ to more than a meter were common on unmined plateaus (Photo 1). This habitat is an important feature of all less disturbed sites such as Zenda, Idarganj and Mogalgad. On Masai, boulders have been removed by villagers for construction. Boulders have BSC, chlorophytic lichens, as well as niches for higher plants to establish. Moss cushions and ferns, lithophytes such as Hoya spp., orchids (Aerides, Dendrobium) are frequently found on boulders. 
They provide refugia for a wide range of invertebrates, reptiles and amphibians as well as elevated display points essential for many breeding amphibians.

\subsubsection{Rock crevices}

Rock crevices provide a microclimate for mosses, ferns and some angiosperms. Indopoa paupercula (Stapf) Bor, Tripogon bromoides Roth, Fimbristylis tenera Schult are dominant in crevices. Neanotis spp. Glyphochloa spp. are common in crevices. They provide refugia for amphibians, reptiles and invertebrates and as such permit some resident amphibians to persist on the site through the dry months.

\subsubsection{Soil filled depressions}

Shallow soil filled depressions (less than $30 \mathrm{~cm}$ depth) on Zenda as well as Masai sites have high species richness of herbs and include Paspalum canarae (Steud.) Veldkamp, Smithia spp., Habenaria spp. Pycreas spp., Jansenella griffithiana (C. Muell.) Bor, Coelachne minuta Bor, Linum mysorense B.Heyne ex Wall amongst many others. Deep soil filled depressions (soil depth greater than $30 \mathrm{~cm}$ ) have tall herbaceous vegetation or low woody species.

Areas with soil depth more than $1 \mathrm{~m}$ on Zenda site support woody vegetation of Carissa congesta Wight, Catunaregam spinosa (Thunb.) Tirveng., Xantolis tomentosa Raf. etc. Forest patches of Memecylon Syzygium-Actinodaphne type are seen on undisturbed sites such as Zenda and Idarganj but the vegetation is generally low, 3-5m high due to strong winds and extreme climate on the plateau tops. Ficus spp. establish in deep clefts along the plateau edges. All sites have a rich fauna of Formicidae with genera associated with forest including Myrmicinae (Crematogaster spp.) and Formicinae (Polyrachis spp.).

\subsubsection{Ephemeral Flush Vegetation (EFV)}

Ephemeral Flush Vegetation (EFV) grows on gently sloping areas that allow slow seepage of rainwater through existing vegetation (Photo 5). It is a dominant community on unmined sites, and covers large areas of ferricrete sites. The community is dominated by Utricularia spp. (U. purpurascens Grah., U. albocaerulea Dalz., U. praeterita P. Taylor) and Eriocaulon spp. (E. sedgwickii Fyson, E. eurypeplon Koern., E. stellulatum Koern., etc.) (Photo 5). Swertia minor (Griesb.) Knobl., Cyanotis fasciculata, Drosera indica L., Dichanthium spp. and some other small ephemerals are common.

\subsubsection{Depressions filled with water pools}

During the monsoon, water accumulates on the plateaus filling depressions of all sizes. Pools of various depth on the sites range from 'micro pools' (up to $20 \mathrm{~mm}$ ), to shallow pools (20-150mm deep), deep pools $(150-300 \mathrm{~mm})$ and finally semi-permanent ponds ( $>300 \mathrm{~mm}$ in depth). Pool complexes with varying hydroperiods are not common in the wider landscape and are a valuable ecological resource (Brendoncket et al. 2015).

These are sites for aquatic invertebrates. Temporal changes in aquatic invertebrates were seen from early occupants derived from the egg banks and aestivating larvae of permanent residents (e.g. Odonata and Coleoptera) joined later by active dispersers. Nymphs of several genera of Heteroptera were observed on the Masai and Zenda. The communities in ferricrete pools shift in phases with early ephemeral taxa such as the Hemipterans of the genus Micronecta dispersing and late emergers replacing them.

The vegetation in the pools and on the margin can be broadly classified as flooded terrestrial vegetation and aquatic vegetation. Aquatics like. Marsilea spp., Rotala spp. and members of Cyperaceae (Cyperus spp., Pycreas spp.,), Poaceae (Eleusine indica Gaertn., Oryza sativa L.) are frequent in deep water bodies on plateaus. Polygonum plebeium R. Br. form dense growth on dried up pond soil. Aquatic invertebrate species richness is correlated with the amount of vegetation in a pool. (Thorpe et al., in press).

Micro pools are used by a number amphibian species to deposit spawn in, some species' larvae remain in the pool with others grazing on the BSC on the wet surfaces of the boulders.

Shallow pools (Photo 3) are highly ephemeral in nature and are colonised by small aquatic coleopteran adults which are known to be active dispersers Dytiscidae Microdytes spp., Hydroporinae Clypeodytes spp. and Hydrophilidae Regimbartia spp. Larvae of a number of anuran species can be found alongside the invertebrates. Vernal pools are a scarce and recognised habitat that are recognised as being worthy of protection (Gioria in Yee 2015, Ch.7).

Some deep pools may retain water for a month or so even after the rain stops. Their vegetation is mostly similar to shallow pools but may also have floating hydrophytes. They have a rich invertebrate fauna which varies in community assemblage and species richness between high level sites and those below the escarpment. Members of the order Odonata, sub-orders Anisoptera and Zygoptera use the pools as breeding sites. Aquatic coleopterans belonging to five families and 31 genera have been recorded from pools on unmined ferricretes (Table 1). Water Scorpions (Family 
Nepidae) are frequently encountered. Coleopterans only found in deeper pools include Hydrophilidae Hydrobiomorpha spp. and Hydrophilus spp.; Dytiscidae Cybister spp., Gyrinidae (Dineutus indicus and Orectochilus Patrus spp.) Hemiptera Heteroptera are represented by 7 families and 8 genera (Un-mined sites, Table 1). Decapoda are frequently encountered belonging to the family Potamidae with a number of species observed.

Semi-permanent ponds retain water almost till end of winter and may be dry or with little soil moisture during the summers. Their vegetation consists of typical hydrophytes including green algae, Nymphoides spp., Ludwigia sp., Persicaria glabra (Willd.) Gomez and Crinum viviparum (Lam.) R. Ansari and V.J. Nair.

In Amboli, trees overhanging such pools are used by foam nesting amphibians for example Rhacophorus malabaricus.

\subsubsection{Drainage channels}

At places, drainage channels of $100 \mathrm{~mm}$ width or more but very little depth are seen running downhill into small puddles. Cryptocoryne spp. occupy the sides of such drainage channels.

\subsubsection{Escarpment walls}

Steep escarpment walls support a wide diversity of snails, aquatic coleopterans, frogs and cryptogamic flora during wet period. Mammals such as mouse deer, sloth bear and civets use the escarpment walls and caves as refugia and breeding sites. The invertebrate communities of the seeps along the escarpment edges are under researched.

\subsection{Ecosystem services}

Ferricretes provide supporting, provisioning as well as cultural ecosystem services. Provisioning services are principally water, fodder and to a minor extent medicinal plants together with fish and crabs for food.

Grazing and use of rock pools by wild animals as well as livestock is seen on all the unmined ferricretes in study area. Many plateaus are grazed by domestic livestock during the monsoon. Fodder is also harvested and carried off for use after the monsoon period.

Loose rocks have for a long time provided building material for the construction of dwellings and enclosure walls or simply to demark boundaries.

Lateritic plateaus are essential for recharging perennial springs (Buono, 2013). Zenda and Masai ferricretes have perennial springs along the edges, on which villagers are heavily dependent. Villages gain irrigation and drinking water (Lad, 2009) originating from the plateaus. In addition it enables a range of aquatic habitats to persist below the high level plateaus well beyond the end of the rains.

Fish and crab collection from plateau ponds is common in monsoon. Medicinal plants such as Swertia densifolia (Griseb.) Kashyapa, Iphigenia spp. are collected from the plateaus.

Supporting services include pollination. The mass flowering of plants provides an intense resource for a number of pollinators which provide an essential ecosystem service for a range of crops in the surrounding area (Hobbhahn, et al. 2006).

Cultural services including religious and more recently recreational uses are also provided by ferricretes. Most ferricretes have locally important shrines and memorial stones. The caves below Masai plateau are believed to have been used by Pandavas, mythical characters from Indian epic Mahabharat. This plateau also has historical significance and has become a significant tourist destination due in part to its proximity to Kolhapur. Two temples of the goddess Masai are important shrines visited by thousands of people annually. A temple with ancient carvings is present on the Zenda ferricrete. Regulatory services such as those for water (holding capacity and purification) and carbon sequestration have not been studied so far.

\subsection{Unique features of ferricretes}

Future research, especially on invertebrates and cryptogams will surely reveal high diversity and yet unknown ecological functions and as such they have significant biodiversity and educational value. Many new and endemic species have been described from ferricretes in the NWG region. Ceropegia jainii Ansari and Kulkarni, Merremia rhyncorhiza (Dalz.) Hall. f. are endemic threatened species reported from Amboli ferricretes. Amphibian species such as Raorchestes ghatei (Padhye 2013), Indirana chiravasi (Padhye 2014) Amboli Toad, Xanthophryne tigerina (Biju et al., 2009) were reported from one or a few sites in this region. Endemic and threatened species restricted to one or few ferricrete sites have also been documented from Satara district and in low level ferricretes (Watve, 2013). The scientific findings suggest that each ferricrete site may have unique and as yet undescribed biodiversity, owing to its functioning as "habitat island" (Thorpe et al. in press and Lewis et al. in press). Biodiversity of ferricretes differs widely from that of the surrounding weathered landscape. The scarcity of soil, extremes of environmental changes lead to formation of plant communities specific to each microhabitat which 
are not seen elsewhere.

The microhabitats and associated plant and animals communities described above are characteristic of ferricrete habitats. Hence, one can safely assume that these were present on the mined ferricrete sites in the past. In the absence of baseline documentation from mining sites the restoration can be compared with these reference sites.

\subsection{Impacts of mining and restoration efforts}

In the NWG, Bauxite mining follows the open cast mining model. In the mining process overburden of soil and vegetation is removed (Photo 2). Ore is removed by blasting or ripping with bulldozers and exported from the site for processing. Open cast mining completely removes the ferricretes surface, hence none of the microhabitats and plant and animal communities described above can be sustained on an active mining site. A wider secondary effect is impact of the removal of resources from visiting groups, for example birds and predators who hunt in the open space afforded by the plateau or those affected off site, for example stream communities in water bodies fed by springs below the site. The primary and secondary impacts have to be mitigated and compensated in the restoration process.

\subsection{Mitigation}

Mitigation is the process of preventing, reducing or offsetting any adverse impact of development on species resident on the site prior to commencement of work (Drayson and Thompson, 2013, Maron et al., 2012). Ecological restoration (Benayas 2009), habitat restoration (Miller and Hobbs 2007) or ecosystem reconstruction (Cooke and Johnson 2002) have the simple sounding objective of reversing the damage or degradation caused by human activity. Within that broad remit there are subsets of activities that can be usefully considered when planning works to achieve the ideal of 'no net loss' of habitat, populations or the resources necessary for their long term persistence (Miller and Hobbs 2007; Maron et al., 2012; Drayson and Thompson 2013). It belies the significant difficulties involved in replacing the previous communities and the resources they need to exist as self-sustaining communities. The restoration process should address not only the biodiversity but the ecosystem services that had previously been provided by the site. The provision of some ecosystem services are correlated to biodiversity and therefore an improvement in one will help the other. In the context of a site subject to open cast mining that may seem a difficult target to achieve but it must remain the primary objective. In some models, translocation of fauna is included, but this is difficult for almost all taxa.

\subsection{Restoration}

Two options are available for restoration: the traditional restoration based on natural recolonization and technical restoration where the processes involved, from land reclamation to species introduction, are all managed.

\subsubsection{Outcome of traditional Restoration}

The results of natural recolonization can be seen on partially mined or abandoned sites in the study area. Observations on Idarganj and Zenda sites show that the parts of the area that were explored for testing the ore quality, about 20-25 years ago are still almost barren areas in the midst of intact plateau vegetation. They lack the habitat heterogeneity of an undisturbed site. A thin BSC has established on these areas, but only select species of EFV, which have wind-dispersed seeds in large quantities (Eriocaulaon spp., Utricularia spp., Hedyotis spp.) have recolonized despite a seed source being adjacent. Tropek et al., (2012) point out that, significantly similar sites close to the restoration site are essential if rare pioneer species are to be able to recolonise, on Indarganj and Zenda recolonization is patchy. Some taxa will face specific difficulties. For example many tropical tree species' seeds are heavy and hold a large amount of free water giving them a very limited viability period and restricted dispersal reliant on suitable vectors (birds and mammals) remaining active in the post mining area. Other plant groups who depend on rare habitats such as those dependent upon rocky vernal pools will not be available unless the surrounding undisturbed source habitat has such resources within the relevant dispersal range.

\subsubsection{Limitations of technical Restoration}

The second option is technical restoration. In theory, technical restoration can be undertaken in steps, for example : restoration of substrate, re-creation of microhabitats, re-establishment of cryptogrammic crusts and later higher order flora, introduction or establishment of faunal communities of invertebrates, vertebrates, development of ecosystem processes interlinking flora and fauna and simultaneous refurbishing of ecosystem processes. Continuous monitoring to ensure self maintenance of the ecosystem will be required.

In practice, several challenges have been noted by Kulkarni et al., (2013) who have carried out technical restoration of Kasarsada and Durgamanwad mining 
sites (Photo 6).

- Lack of porosity of the clay layer left after ore removal damaging downslope springs. They use machines to scratch the surface of hard clay layer and machines to create cracks which can later be filled up.

- Lack of or scarcity of restoration material (soil/ overburden) leading to import of exotic material. They used two types of substrate; soil from surrounding intact plateau and silt from village waterbodies.

- Extreme sun, wind and weather conditions unsuitable for growth of most tree species except those locally adapted species present prior to mining.

- Challenges in restoring water drainage.

- Preference of the clients regarding the forest model of restoration owing to the directions of the monitoring and evaluation committee. (Restoration sites are regularly inspected by committees appointed by regulatory bodies such as Pollution Control Board, Ministry of Environment and Forest, Indian Bureau of Mines etc. Forest model is a well recognized model for restoration of mining sites, hence any deviation is likely to invite criticism from the monitoring committee.)

Availability of substrate is the first challenge in technical restoration. Removal of ore leaves a hard layer of clay, poor in porosity and poor in nutrients at the same time destroying habitat integrity and all microhabitats unsuitable for growth of vegetation. This poses a major challenge in restoration as the clay layer is devoid of organic matter, has no fissures and is unsuitable for establishment of BSC which is a soil precursor on ferricretes. Standard procedure in mining restoration includes storage of overburden and backfilling. This is possible when large amount of overburden of soil is present. Hence it is unsuitable for ferricretes which have small amount of overburden and a limited quantity of soil. A seed bank stores seeds as a source for planting in case seed reserves in nature are destroyed. Imported soil will lack the seed bank of endemic and adapted species and may contain propagules of invasive species. So far there are no techniques or seed banks established for propagation of ferricrete plants nor are mycorrhizal associations and dispersal vectors fully known. Thus, restoration has to rely on existing seed banks or natural colonization process automatically excluding many species. Leaving a part of ferricrete surface intact during mining did retain seed banks, but the amount of recoverable seed material is very small, as most species are wind dispersed and thus scatter very small sized seeds over wide areas. This makes collection or storage of seeds very difficult. Similar issues exist regarding fauna for replacing communities. Ecological details for almost all ferricrete specialists are absent from the literature.

Waterhouse, et al., (2014) found that soil microbial communities are sensitive to restoration process and the only way of preserving them was to remove, carefully store and replace the top $300 \mathrm{~mm}$ of topsoil at the same time limiting the depth of storage piles. This process was also suggested for the conservation of soil invertebrates by Majer et al., (2013). Mycorrhizal association of plateau plant species are not known but are common in low nutrient systems such as lateritic plateaus. This aspect has not been considered in bauxite mining restoration efforts in the study area.

In Durgamanwad, silt was procured from village tanks in surrounding areas, for plantation purposes (Kulkarni et al. 2013). However, it is a poor alternative as silt is very different material from the original sandy - loam soil found on plateaus and has seeds of ruderal and invasive species alien to ferricrete habitats. Disturbance and importation of alien material (for construction fence) has been demonstrated to introduce potential invasive plants along the fence-line on the Kas plateau, a ferricrete in Satara district.

Soil from an intact plateau is a better option, but may not be available in large quantities as the soil layer on a ferricrete is generally shallow or inaccessible, located in depressions and surface cracks. Removing soil from intact ferricretes would also disturb an unmined and intact ecosystem extending the area disrupted. In Durgamanwad, soil was collected from adjacent unmined plateau and spread on the hard face to start restoration. However, without the BSC and without the crevices, most thinly spread soil material is just washed away during the heavy rains as the surface topography did not provide for depressions to allow soil to accumulate. It is thus critical for successful restoration to allow for and to encourage the formation of biological crust over a topographically heterogeneous surface before undertaking plateau flora restoration, but there is no established technique for this and natural formation of BSC takes several years.

Storage of overburden at a depth over $1 \mathrm{~m}$ damages the biota within the spoil (Waterhouse et al., 2014). In the active mining sites it was seen that the piled up overburden is quickly colonized by Senecio spp., Blumea spp., Themeda spp., Heteropogon spp. from surrounding scrub vegetation, which will add their 
seeds into soil. Backfilling, if practised, does not rebuild the plateau surface or the surface drainage pattern as was present in the intact habitat and hence cannot support the plant or animal communities of the pre-mining stage.

One of the major problems observed on restoration sites was the lack of heterogeneity in micro-habitat provision, specifically the absence of boulders, rock pools of all depths, shallow depressions or crevices which are all essential microhabitats for the reestablishment of amphibians, reptiles, invertebrates and flora. Kulkarni et al. (2013) mention recolonization of common shrub and tree species on restored areas. EFV species (Utricularia spp., Eriocaulon spp.) were also seen naturally colonizing restored areas. However, establishment of geophytes (Crinum spp., Chlorophyum spp.) and lithophytes was not seen due to absence of boulders and deep crevices.

Restoring the drainage pattern and diversity of aquatic habitats in the mined out area is a major challenge. Large pools of rain water form in excavated areas on the plateaus (Photo 4). However, the water was mostly used for mining tasks, such as washing of vehicles, sprinkling water over ore to reduce dust and for plantation activities. Due to this, the water was in regular use and aquatic flora seen on reference sites (Cyperus spp, Pycreas spp. Eleocharis, Oryza etc.) is absent. Such tanks do not have the low angle edge providing shallow areas required by many aquatic invertebrates (Gioria in Yee 2015 Ch. 7). Amphibian and invertebrate fauna that require aquatic vegetation cannot establish. Except a few large mammals, restoration of invertebrates or herpetofauna has not been reported.

\section{Legal issues in restoration}

Norms regarding EIA of projects such as mining were very weak and prescriptive in India until 1998. Major amendments in Environmental Law made in 2006 make it necessary to conduct EIA and Social Impact Assessment (SIA), for certain projects. Recent EIAs of proposed bauxite mining at Girgao, Ringewadi ferricretes (EIA, 2013) were conducted during March 2011 to May 2011 (summer) as the Terms of Reference (TOR) set by the Ministry of Environment and Forest asked for single season, non-monsoon data. As a result the EIA and EMP completely missed out the details of the seasonally diverse plant and animal communities. EIA of Mogalgad site (EIA, Mogalgad, 2013) lists characteristic ferricrete species. However, EMP of the site gives suggestions regarding plantation of trees, mostly exotic, aliens such as Acacia spp. Casuarina spp., etc. The EIAs do acknowledge the presence of waterbodies and springs in the villages but importantly do not comment on the impact of mining on these ecosystem services. In the absence of rigorous EIA and baseline data, it is not possible to create a sound EMP or to assess the success of restoration efforts.

EIA of Durgamanwad, Kasarsada and Idarganj mines were conducted several years ago, when the understanding of lateritic plateau ecosystems was extremely poor. The leases were not renewed mainly because of environmentalists protesting on various grounds against mining (Vagholiar and Moghe, 2003). Idarganj mining was stopped on the basis of unique biodiversity values and the presence of the plateau in Radhangari Wildlife Sanctuary, at present Sahyadri Tiger Reserve. On Durgamanwad site extension of the mining lease and forest clearance was refused as it was within $10 \mathrm{kms}$ aerial distance from the Radhanagari Wildlife Sanctuary. On Kasarsada site, lease was not renewed and the site was returned to forest department. In both the cases, continuation of restoration efforts by the corporate agency is unlikely.

As per the notification (G.S.R. 330(E) Part II, Section 3 , Sub-section (i) $10 / 04 / 2003$ ) issued by the Government of India, Ministry of Mines Final Mine Closure Plan is to be prepared and approvals are to be taken as a part of the Mine Closure Plans. Final Mine closure activities are to be started towards the end of mine life and may continue even after the reserves are exhausted and/or mining is discontinued till the mining area is restored to an acceptable level by the appointed government regulatory bodies. However, restoration being a long term and dynamic process, the time period required to consider a restoration as "acceptable level" also needs to be finalized. The financial and technological responsibility to maintain the restoration at the acceptable level post mine closure, ensuring no degradation occurs after withdrawal of agencies also needs to be clearly stated and shared by the mining companies and government or private owners of the land.

The Wildlife Protection Act (1972) is only applicable to designated protected areas (National Parks, Wildlife Sanctuaries) and wildlife in different schedules but sites such as Zenda or Mogalgad are not included in protected areas. Plateau fauna, dominated by invertebrates and cryptogams is not included in the schedules of WPA and therefore does not get any special protection.

Kulkarni et al., (2013) mention that regulating agencies only recognize specific models of restoration 
which are forest, grassland, agriculture etc. while plateau (ferricrete) flora restoration could be considered only in later stages. There is so far, no legal obligation on the mining company to restore a ferricrete to its unique pre-mining biodiversity. In case of Kasarsada and Durgamanwad, the forest (tree plantation) model was chosen in consultation with the company as "it is well recognized by regulating and monitoring authorities and an easier model to restore to, with well established technology" (Kulkarni et al. 2013). This limited the possibility of restoration of original biodiversity of ferricretes on this site. It is necessary for the regulating and monitoring authorities to understand the importance of restoration to pre-mining habitat. To restore to an alternative ecosystem will automatically exclude all specialist species. Some specific social issues are also presented by mining restoration. None of the studies or EMPs offer economic assessments which weigh the pros and cons in terms of valuation of livelihood impact of the loss of ecological services against the gain in terms of employment, infrastructural development or social uplifting of the rural communities in sustainable manner. In the pre-mining stage, the ferricrete habitats are common property resources, and villagers have rights of access and withdrawal of fodder, medicinal species, water and worship at shrines. This access had continued even in Reserve Forest (RF) areas. However, during the mining stage, the areas are secured by the company to prevent access of local people and livestock. This is a necessary procedure considering the valuable ore, machinery and also regular blasting for minerals, which makes the area risky to access. Abandoned mines pose many risks, due to dumps, deep waterbodies etc. Allowing free-access to restored areas post-mining may not be feasible as it can lead to disturbance in the restoration process. The sustainability of the restoration, after the end of mining lease is questionable, as the corporate body is not under any legal obligation to continue restoration when the lease ends.

The legalities regarding grant of access to local communities post-mining or post-restoration have never been clarified. Certain community rights over RF areas or even private areas are recognized under present laws. For example, the Forest Rights Act (2006) and Biological Diversity Act (2002). It is unclear if the same rights will continue after mine closure. This will have long-reaching effect on the sustainability of the restored ecosystem, e.g. if local communities do have the rights to using the restored area for collection of forest produce (fodder, fuel etc.), then the model of restoration will need to be planned and executed in a manner to allow extractive activities at sustainable level. Otherwise over extraction may lead to loss of the restored biodiversity. It is not known if grazing and extraction are regulatory processes which create and maintain the plateau ecosystem so their exclusion may directly lead to a novel ecosystem even if the site is appropriately restored.

\section{Global restoration scenario with special reference to bauxite mining}

The published records of post bauxite mining restoration from northern WG bring out the challenges in restoration of the plateau flora. They do not offer any evidence of restoration leading to return of the site to the same flora and fauna as previously existed on the plateau sites, or to local reference sites.

The international evidence of post bauxite mining restoration is uniformly negative in the long term. Mining followed by restoration of all types leads to a shift in community structure from the pre-mining assemblage, even after 37 years, irrespective of the restoration model or level of expenditure (Majer et al. 2013; Courtney, et al. 2014). The changes affect species at all scales from microbial to vertebrate. Herath et al. (2009) found that restored laterite sites shared only 12$37 \%$ of shrub species with natural sites. Gould (2012), also working on post bauxite mines, found plant community composition was significantly different from un-mined sites after 23 years with key framework species absent. Using ants as bio-indicators, Majer et al., (2013) found the community was still measurably different to reference sites 37 years post mining. In a meta-analysis of 20 studies using invertebrates to assess post bauxite mining recovery Majer et al., (2007) found tree monoculture damaged recovery. The shift in plant community assemblage is reflected in birds both in numbers and species richness (Brady and Noske 2010). Intra-specific relationships must therefore be considered when assessing recovery and not just the presence of individual species (Majer et al., 2007). In spiders the community on mined sites was still distinct from reference forest sites but there appears to be a trajectory, with the oldest mined site being more similar to reference forest than younger mined sites (Majer et al., 2007). However, even when pre-mining diversity is achieved the species mix of invertebrates may differ (Majer et al., 2007).

Alcoa has noted success in recolonization of vertebrate groups post bauxite mining. In mammals, recolonization after 10 years is linked to resource availability in terms of food and shelter and the species 
source pool (Nichols and Grant 2007). Total of 95\% of bird species were found to recolonize. They do not comment on the $5 \%$ that did not recolonise and that small group may include rare species (Nichols and Grant 2007). However, they have compared their success with some other studies of restoration and concluded that rates of bird recolonization vary, being more rapid for mesic forested areas but not so for semiarid shrub-steppe areas. The figure in reptiles was similar with $87.5 \%$ returning, but reptile species numbers and abundance tend to be lower in restoration than in unmined forest (Nichols and Grant 2007). They have suggested that variable habitat requirements of the vertebrates species need to be understood and where possible met in a cost-effective manner to ensure their successful recolonization after restoration. Robust and long-term monitoring of mined and restored sites will be required to check if biodiversity in Western Ghats also responds in ways similar to that elsewhere. At present such long-term studies are lacking. Therefore, success of restoration efforts of mines, especially bauxite mines remains unknown.

Phillips (2012) suggests that bauxite mining in Andhra Pradesh is unsustainable owing to environmental and social impacts. Therefore, there is a substantial case to refuse the mining applications at sites such as Mogalgad, Ringewadi, Burumbal, Girgaon, Dhangarwada in Kolhapur district in order to protect the unique floral and faunal communities and ecosystem services.

\section{Conclusion}

Any conclusion, as would any EIA, will be based upon incomplete knowledge of the biota and ecology of the high level ferricretes. Therefore our comments need to be considered as a view based upon our study, published literature and knowledge at this point in time.

Based upon our own findings and those published by others of post mining restoration outcomes we find :

- New species are being described from the high level plateaus that are known to be, or are suspected to be, unique to a single site. Given the rate of discovery of new species is relative to exploratory time and taxonomic effort it seems reasonable to hypothesise that every high level plateau can be expected to house unique taxa.

- A ferricrete, together with its unique micro-habitat heterogeneity and ecosystem services, cannot be recreated by ecological restoration to the pre-existing community. Current restoration practice has failed to recreate the range of micro-habitats or hydro- logical patterns that existed pre-mining.

- No evidence was found that the ecosystem services provided by a high level ferricrete could be, or have been, replicated.

- Current legal requirements do not recognise ferricretes as a non-forest ecosystem and therefore the current legal restoration guidelines are outmoded.

- The current legal framework does not identify the need to preserve ecosystem services for the communities around the ferricrete.

- The current legislative requirements exclude assessment of off-site systems impacted by the application, for example stream and escarpment communities.

- Detailed long term scientific research examining success of mine restoration, and establishment and recolonization of diverse taxa, is lacking.

Therefore mining of any ferricrete plateau is likely to cause irreplaceable loss of unique species, ecosystem services and key biogeographic features of one of India's and the world's most biodiverse locations. A similar impact is anticipated for ferricretes in the Konkan, however we recognise the impact of changes in hydrology and landscape may be less around low level ferricretes than for the high level plateaus. In the view of irreplaceable loss of unique and sensitive biodiversity and critical ecosystem services, bauxite mining in the Western Ghats biodiversity hot-spot should be subject to an immediate moratorium until the biodiversity value and ecosystem services of the sites are fully understood and can be weighed against the economic gains from mining. At the same time, mine closure plans should be implemented with the application of ecological restoration practices to the currently worked mining areas and old abandoned bauxite mines in the region to ensure at least partial mitigation of the impacts.

\section{References}

Azapagic, A. (2004) Developing a framework for sustainable development indicators for the mining and minerals industry. Journal of Cleaner Production, 12 (6), 639-662.

Balasubramaniam, K. S., and Paropkari A. (1975) Mineralogy and genesis of bauxites of Nagardaswadi Plateau, Kolhapur District, Maharashtra State (India). The Canadian Mineralogist, 13(3), 222-226.

Benayas, J., M.,R., Newton,A.,C, Diaz, A., and Bullock, J.M. (2009) Enhancement of biodiversity and ecosystem services by ecological restoration: A 
meta-analysis. Science, 325 (5944), 1121-1124.

Bharucha, E.K., (2010) Current ecological status and identification of potential ecologically sensitive areas in the Northern Western Ghats. Report by : Institute of Environment Education and Research; Bharti Vidyapeeth Deemed University. Pune, Maharashtra, India.

Bhattarai, U., Tetali, P., and Kelso, S., (2012). Contributions of vulnerable hydrogeomorphic habitats to endemic plant diversity on the Kas Plateau, Western Ghats. SpringerPlus, 1(1), 25.

Biju, S., Van Bocxlaer, I., Giri, V. B., Loader S. and Bossuyt, F. (2009). Two new endemic genera and a new species of toad (Anura: Bufonidae) from the Western Ghats of India. BMC Research Notes 2(1), 241.

Brendonck, L., M. Jocqué, K. Tuytens, B. V. Timms and B. Vanschoenwinkel (2015). Hydrological stability drives both local and regional diversity patterns in rock pool metacommunities. Oikos 124(6) : 741-749.

Buono, J. and Thomas, R. (2013). Natural Springs in the Western Ghats: A Vital Resource Under Threat: Overview, Best Practices and Policy Recommendations for Ensuring Biodiversity and Sustainable Drinking Water. Grampari. [Online]. Available at: file:///G: / Documents / Documents / BiogeographyHydrologyBuono,\%20J,\%20Anatomyu \%20of\%20a\%20spring\%20system.pdf (Accessed : 07/08/2015).

Cincotta, R.P., Wisnewski, J. and Engleman, R. (2000). Human populations in the biodiversity hotspots. Nature, 4040 (6781), 990-992.

Cooke, J. A. and Johnson, M. S. (2002). Ecological restoration of land with particular reference to the mining of metals and industrial minerals : A review of theory and practice. Environmental Reviews 10(1), 41.

Courtney, R., Harris, J. A. and Pawlett, M. (2014). Microbial Community Composition in a Rehabilitated Bauxite Residue Disposal Area: A Case Study for Improving Microbial Community Composition. Restoration Ecology, 22 (6), 798-805.

Directorate of Geology and Mining, Govt. of Maharashtra, Nagpur. (2014) http:// www.mahadgm.gov.inInternalPage.aspx?Antispam $=$ nm9WddrsTcbandMineralInformationID= 6andMyAntispam=pPiwE6B0r42 Downloaded on 10 October 2014.

Drayson, K. and Thompson, S. (2013). Ecological mitigation measures in English Environmental Impact Assessment. Journal of Environmental Management, 119 (), 103-110.
EPA, (1986). The Environment Protection Act http:// envfor.nic.in/legis/env/env1.html Downloaded on 10 October 2015.

EIA, (2013). Environment Impact Assessment report on Bauxite Mining for Ex servicemen Welfare Association (Girgao, Mhalasavade, Ringewadi, Kolhapur District. http://environmentclearance. nic.in/writereaddata/EIA02072015U37EH4ML FinalEIAExservicemenn.pdf. Downloaded on 10 October 2015.

EIA, Mogalgad, 2013. Executive summary of Draft EIA and management plan report. Mogalgad Bauxite Mine. Hindalco. http://mpcb.gov.in/notices/pdf/ Exe\%20sum_Hindalko_Mogalgad.pdf

Escolar, C., Martínez, I., Bowker, M. A., and Maestre, F. T. (2012). Warming reduces the growth and diversity of biological soil crusts in a semi-arid environment : implications for ecosystem structure and functioning. Philosophical Transactions of the Royal Society of London B: Biological Sciences,367(1606), 3087-3099.

Gaitonde, N., and Giri, V. (2014). Primitive breeding in an ancient Indian frog genus Indirana. Current Science, 107 (1), 109-112.

Gaston, K.J., and Blackburn, T.M. (1995). Mapping biodiversity using surrogates for species richness: macro-scales and New World birds. Proceedings of the Royal Society of London, B 262, 335-341.

Giri, V.B. and Bauer, A.M. (2008). A new grounddwelling Hemidactylus (Squamata: Gekkonidae) from Maharashtra, with a key to the Hemidactylus of India. Zootaxa 1700, 21-34.

Goudie, A. (1973). Durricrusts in tropical and sub tropical landscapes. Claredon Press, Oxford.

Gould, S. F. (2012). Comparison of Post-mining Rehabilitation with Reference Ecosystems in Monsoonal Eucalypt Woodlands, Northern Australia. Restoration Ecology, 20(2), 250-259.

Goldsbrough, C., Hochull, D. and Shine, R. (2003). Invertebrate biodiversity under hot rocks: habitat use by the fauna of sandstone outcrops in the Sydney region. Biological Conservation, 109, 85-93.

Herath, D. N., Lamont, B. B., Enright, N. J. and Miller, B. P. (2009). Comparison of Post-Mine Rehabilitated and Natural Shrubland Communities in Southwestern Australia. Restoration Ecology, 17 (5), 577-585.

Hilson, G. and Basu, A. J. (2003). Devising indicators of sustainable development for the mining and minerals industry: An analysis of critical background issues. International Journal of Sustainable Development and World Ecology, 10(4), 319-331. 
Hobbhahn, N., Küchmeister, H. and Porembski, S. (2006) Pollination biology of mass flowering terrestrial Utricularia species (Lentibulariaceae) in the Indian Western Ghats. Plant Biology, 8 (6), 791804.

Joshi, V. C., and Janarthanam, M. K. (2004). The diversity of life-form type, habitat preference and phenology of the endemics in the Goa region of the Western Ghats, India. Journal of Biogeography, 31(8), 1227-1237.

Myers, N., Mittermeier, R.A., Mittermeier, C.G., da Fonseca, G.A.B. and Kent, J. (2000). Biodiversity hotspots for conservation priorities. Nature, 403(6772), 853-858.

Katwate, U., D. Apte and Raut, R. (2013). Diversity and distribution of anurans in Phansad Wildlife sanctuary (PWS), Northern Western Ghats of India. Journal of Threatened Taxa 5(2), 3589-3602.

Krishnamurthy, S. V. (2003). Amphibian assemblages in undisturbed and disturbed areas of Kudremukh National Park, central Western Ghats, India. Environmental Conservation, 30 (3), 274-282.

Krishnaswamy, J., Mehta, V. K., Bunyan, M., Patil, N., Naveenkumar, S., Karanth, K. U., N. Jain, P. Bhargav, and Gubbi, S. (2003). Impact of iron ore mining in Kudremukh on Bhadra river ecosystem. Report submitted to WCS India.

Kulkarni, J., Moghe, K., Gour-Broome, V., and Sekhsaria, P. (2013). Restoration of Bauxite mines, Western Ghats, Maharashtra. Ecological Restoration, 40 , 26-34.

Kumar, S., Bisht, N. S., and Rao, R. N. (1995). Afforestation of Lateritic Pans of Goa - a Case Study. Indian Forester, 121(3), 176-178.

Lad, R. and Samant J. (2009). Environmental and Social Impacts of Mining in the Western Ghats: A Case Study of Warna Basin http://cdn.livediverse.eu/ wp-content/uploads/2009/10/Mining-Paper.pdf Downloaded on 27 September 2012.

Laurence, D. (2011). Establishing a sustainable mining operation: an overview. Journal of Cleaner Production,19, 278-284.

Lekhak, M. M. and Yadav S.R. (2012). Herbaceous vegetation of threatened high altitude lateritic plateau ecosystems of Western Ghats, southwestern Maharashtra, India. Rheedea, 22(1), 39-61.

Majer, J., Heterick, B., Gohr, T., Hughes, E., Mounsher, L. and Grigg, A. (2013). Is thirty-seven years sufficient for full return of the ant biota following restoration? Ecological Processes, 2(1), 1-12.

Majer, J. D., Brennan, K. E. C. and Moir, M. L. (2007). Invertebrates and the Restoration of a Forest
Ecosystem : 30 Years of Research following Bauxite Mining in Western Australia. Restoration Ecology, 15(S4), S104-S115.

Maron, M., Hobbs, R. J., Moilanen, A., Matthews, J. W., Christie, K., Gardner, T. A., Keith, D. A., Lindenmayer, D. B. and McAlpine, C. A. (2012). Faustian bargains? Restoration realities in the context of biodiversity offset policies. Biological Conservation, 155, 141-148.

Michael, D. R., Cunningham, R. B. and Lindenmayer, D. B. (2010). Microhabitat relationships among five lizard species associated with granite outcrops in fragmented agricultural landscapes of southeastern-Australia. Austral Ecology, 35, 214-225.

Miller, J. R. and Hobbs, R. J. (2007). Habitat Restoration - Do We Know What We're Doing? Restoration Ecology, 15(3), 382-390.

Molur, S., Smith, K.G., Daniel, B.A. and Darwall, W.R.T. (Compilers) (2011). The Status and Distribution of Freshwater Biodiversity in the Western Ghats, India. Cambridge, UK and Gland, Switzerland : IUCN, and Coimbatore, India : Zoo Outreach Organisation.

Nichols, O. G. and Grant, C. D. (2007). Vertebrate Fauna Recolonization of Restored Bauxite Mines Key Findings from Almost 30 Years of Monitoring and Research. Restoration Ecology, 15(s4), S116-S126.

Paliwal, R. (2006). EIA practice in India and its evaluation using SWOT analysis. Environmental impact assessment review, 26(5), 492-510.

Padhye, A., Modak, N., Dahanukar, N. (2014). Indirana chiravasi, a new species of Leaping Frog (Anura: Ranixalidae) from Western Ghats of India. Journal of Threatened Taxa 6(10), 6293-6312.

Padhye, A.D., Sayyed, A, Jadhav, A. and Dahanukar, N. (2013). Raorchestes ghatei, A new species of shrub frog (Anura: Rhacophoridae) from the western Ghats of Maharashtra, India. Journal of Threatened Taxa 5(15), 4913-4931.

Padhye, S., Rabet. N. and Ghate, H. (2015). First faunal inventory of large branchiopods (Crustacea : Branchiopoda) of Western Maharashtra, India with taxonomical and distributional comments. Zootaxa, 3904, 208-222.

Phillips, J. (2012). Using a mathematical model to assess the sustainability of proposed bauxite mining in Andhra Pradesh, India from a quantitative-based environmental impact assessment. Environmental Earth Sciences, 67 (6) : 1587-1603.

Porembski, S., Becker, U. and Seine, R. (2000). Islands on Isalnds : Habitats on Inselbergs. In : Bartholott, S. P. A. W. (ed.) Inselbergs, Biotic Diversity of Isolated Rock Outcrops inb Tropical and Temperate Regions. 
Berlin : Springer.

Porembski, S. and Watve, A. (2005). Remarks on the species composition of Ephemeral Flush Communities on paleotropical rock outcrops. Phytocoenologia 35 (2-3), 389-401.

Rahangdale, S. S. and Rahangdale S. R. (2014). Plant species composition on two rock outcrops from the Northern Western Ghats, Maharashtra, India. Journal of Threatened Taxa 6(4), 5593-5612.

Rogers, D. C., and Padhye, S. (2014). A new species of Streptocephalus (Crustacea: Anostraca: Streptocephalidae) from the Western Ghats, India, with a key to the Asian species. Zootaxa, 3802(1), 075-084.

Sand-Jensen, K. and Hammer, K. (2012). Moss cushions facilitate water and nutrient supply for plant species on bare limestone pavements. Oecologia, 170(2), 305312.

Silas, E. G. and Dawson D., E. (1961). Amphipnous indicus, a new synbranchoid eel from India, with a redefinition of the genus and a Synopsis to the species of Amphipnous "Muller". Journal of the Bombay Natural History Society, 58(2), 366-378.

Tropek, R., T. Kadlec, M. Hejda, P. Kocarek, J. Skuhrovec, I. Malenovsky, S. Vodka, L. Spitzer, P. Banar and Konvicka M. (2012). Technical reclamations are wasting the conservation potential of postmining sites. A case study of black coal spoil dumps. Ecological Engineering 43, 13-18.

VaÇulik, A., Kounda-kiki, C., Sarthou, C. and Ponge, J. F. (2004). Soil invertebrate activity in biological crusts on tropical inselbergs. European Journal of Soil Science, 55, 539-549.

Vagholikar, N., and Moghe, K. (2003). Undermining India: Impacts of mining on ecologically sensitive areas. Kalpavriksh, Pune.

Waterhouse, B. R., K. L. Adair, S. Boyer and Wratten, S. D. (2014). Advanced mine restoration protocols facilitate early recovery of soil microbial biomass, activity and functional diversity. Basic and Applied Ecology 15(7), 599-606.

Watve, A. (2013). Status review of rocky plateaus in the northern Western Ghats and Konkan region of Maharashtra, India with recommendations for conservation and management. Journal of Threatened Taxa 5(5), 3935-3962.

Widdowson, M. and Cox, K. G. (1996). Uplift and erosional history of the Deccan traps India: Evidence from laterites and drainage patterns of the Western Ghats and Konkan coast. Earth and Planetary Science Letters, 137, 57-69.

Yee, D. A. (Ed.) (2015). Ecology, systematics, and the natural history of predacious diving beetles (Coleoptera : Dytiscidae). Springer 


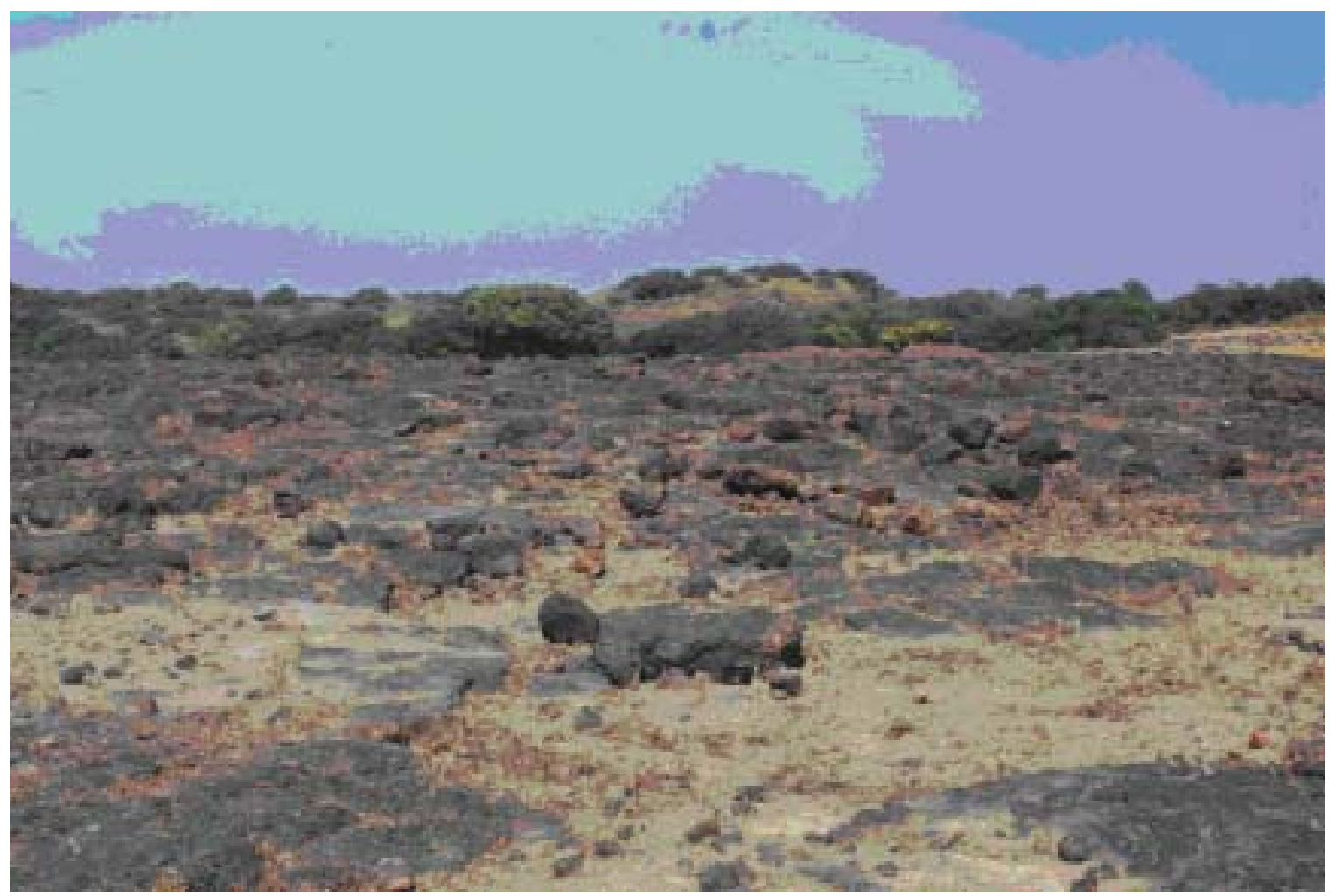

Photo 1 : Ferricrete surface from unmined area: (Mogalgad)

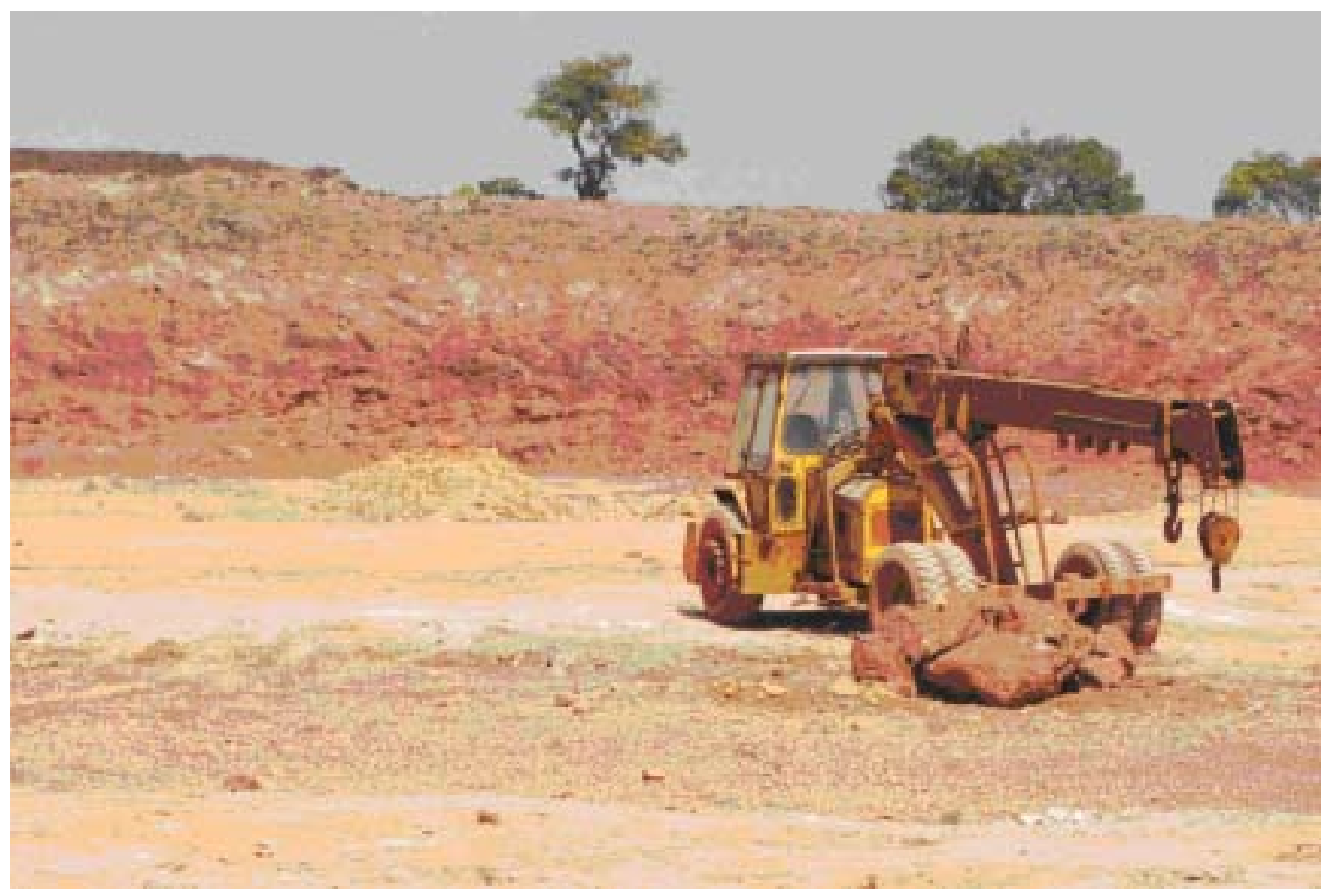

Photo 2 : Exposed layers after overburden removal (Durgamanwad) 


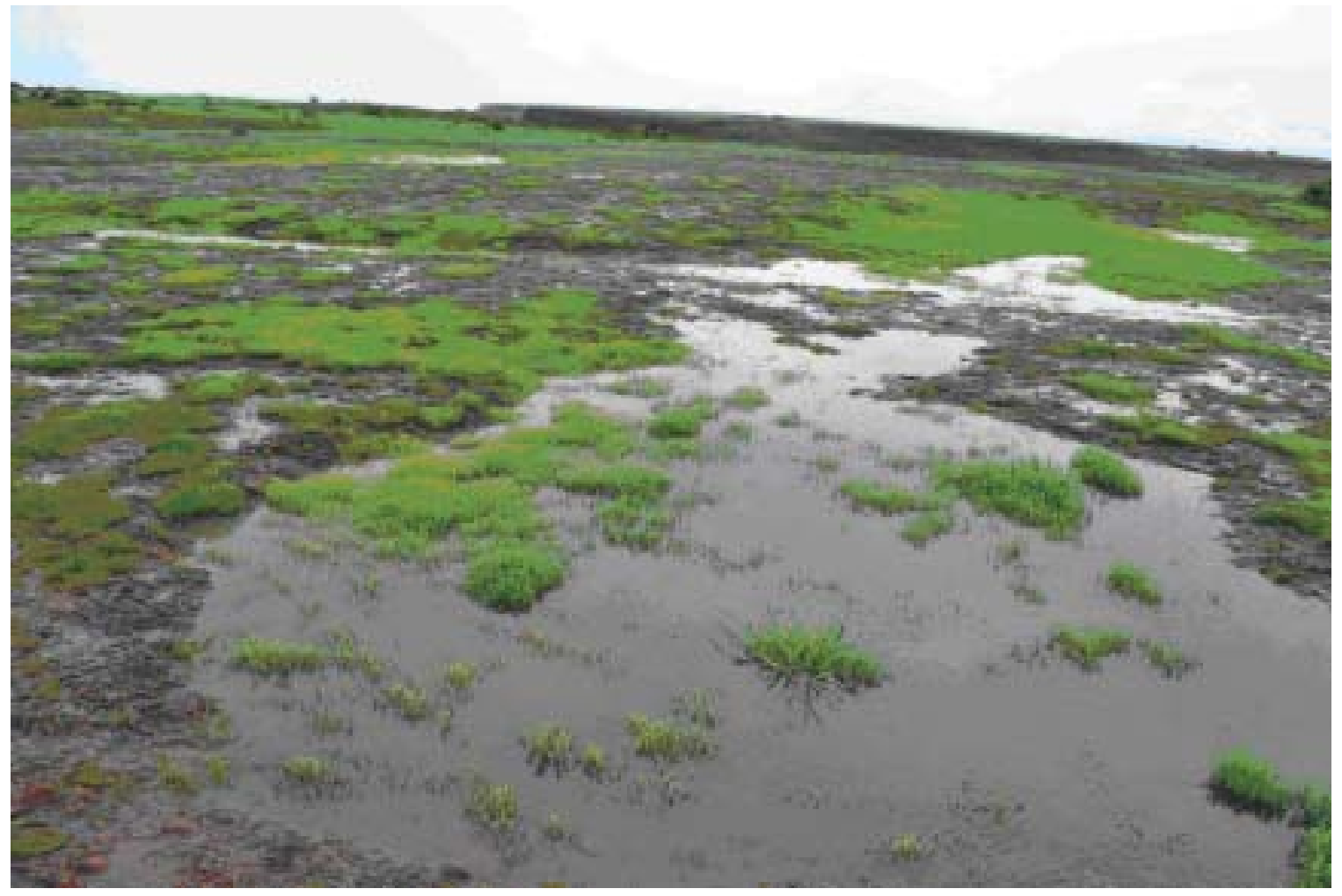

Photo 3 : Shallow pools on ferricretes (Masai)

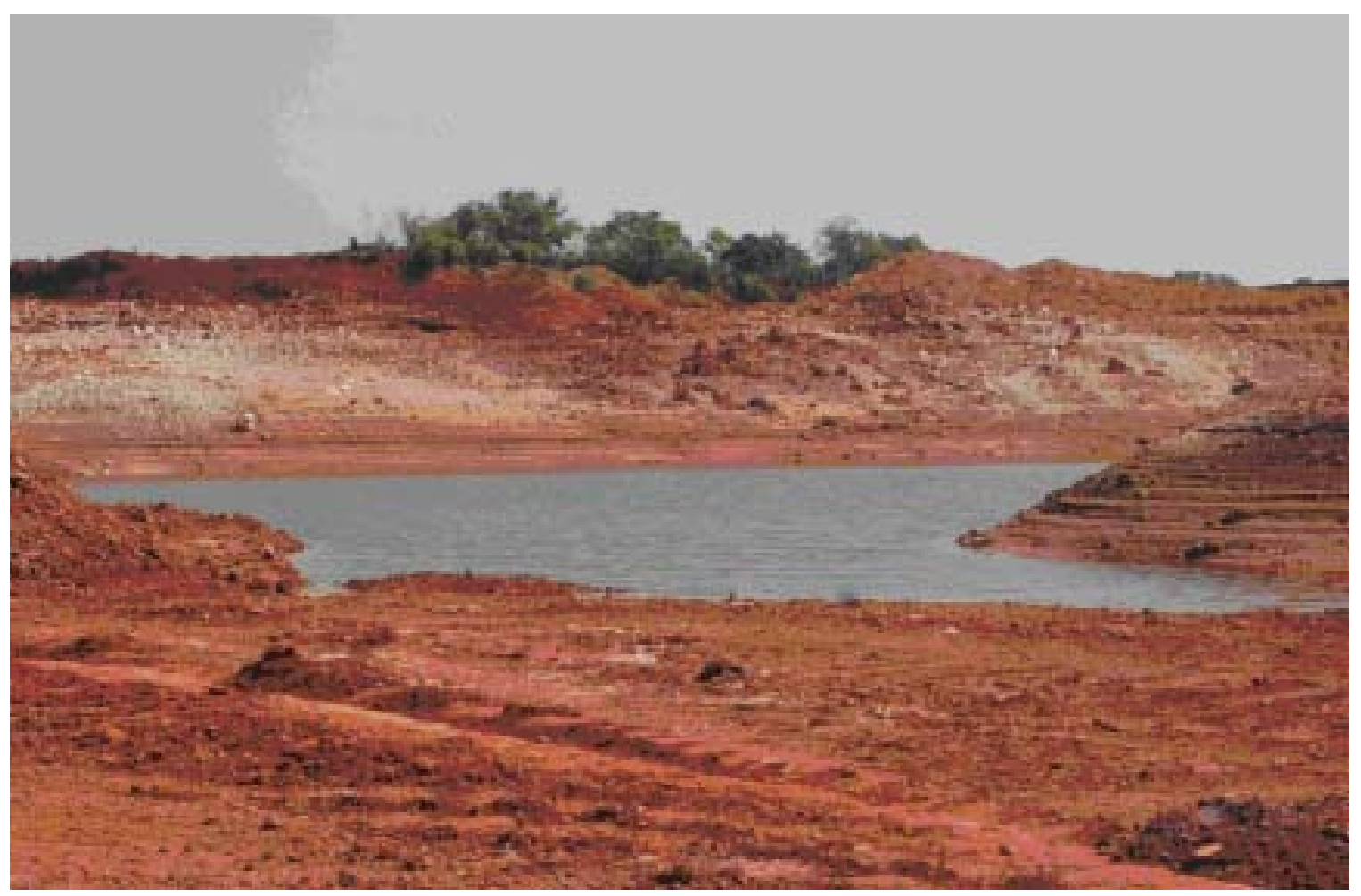

Photo 4 : Water accumulated on excavated area (Durgamanwad) 


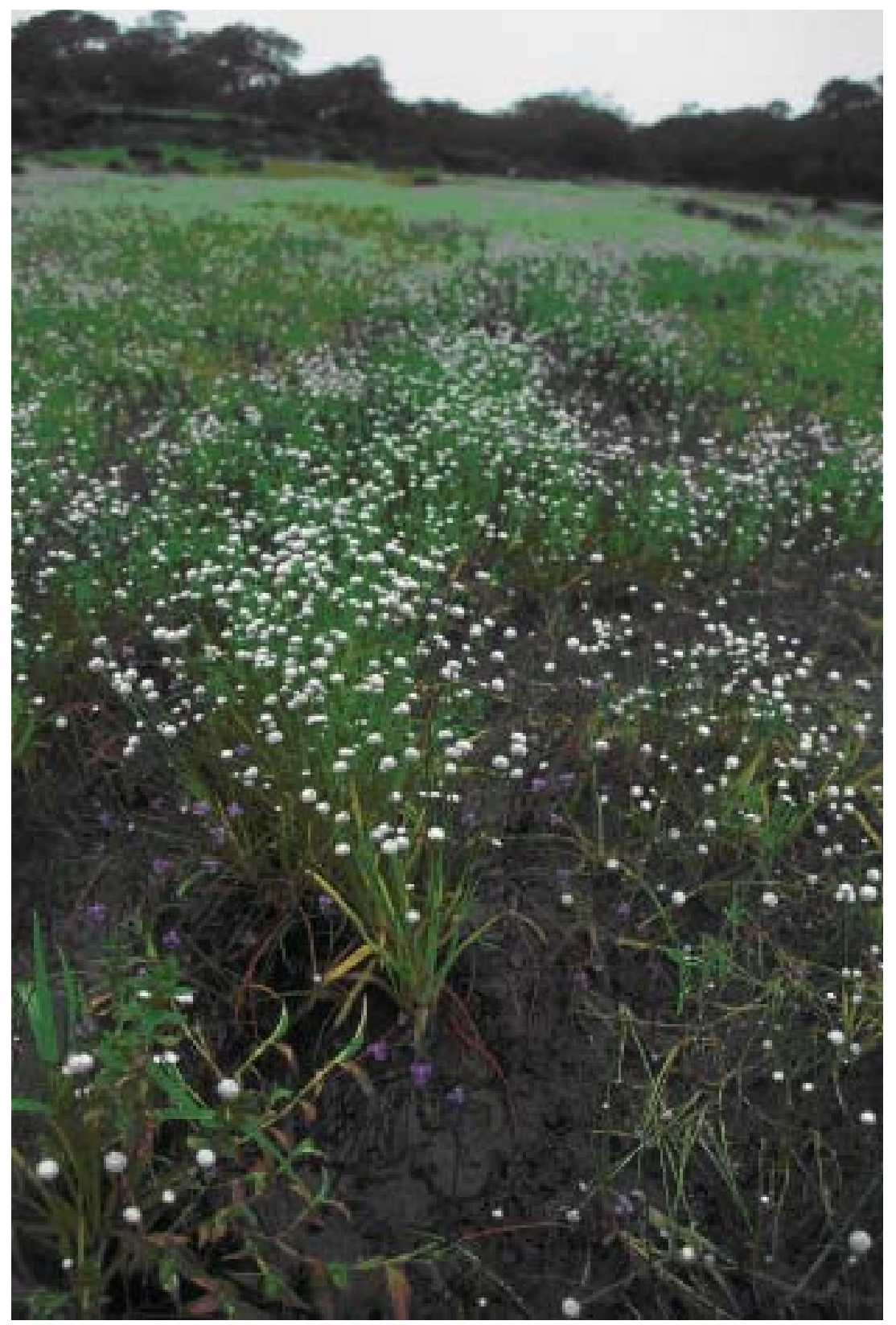

Photo 5 : EFV Vegetation on Zenda site 


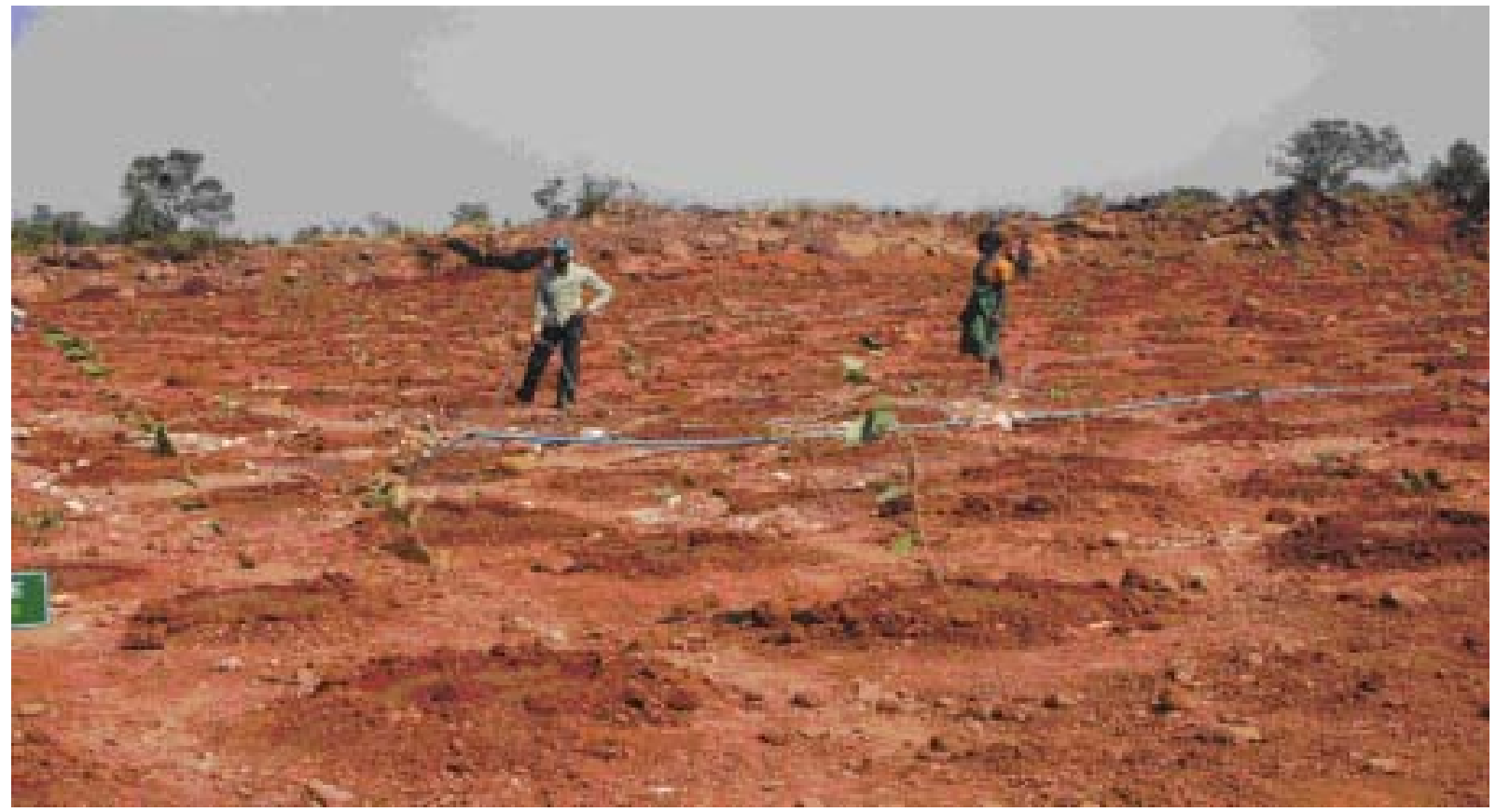

Photo 6: Tree plantation with imported soil 
Table 1 : Site details, [Reserve Forest (RF). Wildlife Sanctuary (WLS)]

\begin{tabular}{|c|c|c|c|c|c|c|}
\hline Site Name & $\begin{array}{l}\text { Zenda- } \\
\text { Dhangarwada } \\
\text { (manoli) }\end{array}$ & Masai & Durgamanwad & Kasarsada & Idarganj & Mogalgad \\
\hline $\begin{array}{l}\text { Altitude } \\
\text { m ASL }\end{array}$ & 1020 & 950 & 900 & 1000 & 1000 & 1029 \\
\hline Latitude & N 16 $55^{\prime} 58.3^{\prime \prime}$ & N16º $49^{\prime} 02.6^{\prime \prime}$ & N16 $27^{\circ} 8.98^{\prime \prime}$ & 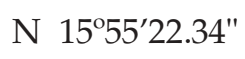 & N16 $20^{\circ} 27.86^{\prime \prime}$ & N 154의 $56.55^{\prime \prime}$ \\
\hline Longitude & E $073^{\circ} 47^{\prime} 42.0^{\prime \prime}$ & $\mathrm{E} 74^{\circ} 04^{\prime} 39.7$ & E73 $57^{\circ} 52.94^{\prime \prime}$ & E $74^{\circ} 7^{\prime} 50.69^{\prime \prime} \mathrm{E}$ & E735'ㄷㄴ.61" & E $74^{\circ} 9^{\prime} 33.83^{\prime \prime}$ \\
\hline Rainfall & $600-800 \mathrm{~cm}$ & $600-800 \mathrm{~cm}$ & $600-800 \mathrm{~cm}$ & $600-800 \mathrm{~cm}$ & $600-800 \mathrm{~cm}$ & $600-800 \mathrm{~cm}$ \\
\hline Remarks & $\begin{array}{l}\text { Mining } \\
\text { proposed but } \\
\text { proposal for } \\
\text { forest } \\
\text { diversion } \\
\text { refused. }\end{array}$ & Not proposed & $\begin{array}{l}\text { Lease not } \\
\text { renewed due } \\
\text { to proximity } \\
\text { to Radha- } \\
\text { nagari WLS }\end{array}$ & $\begin{array}{l}\text { Lease not } \\
\text { renewed }\end{array}$ & $\begin{array}{l}\text { Permission } \\
\text { refused as } \\
\text { the site is } \\
\text { within Radha- } \\
\text { nagari WLS }\end{array}$ & $\begin{array}{l}\text { Mining } \\
\text { permission } \\
\text { granted }\end{array}$ \\
\hline $\begin{array}{l}\text { Land } \\
\text { ownership }\end{array}$ & $\begin{array}{l}\text { Mostly RF } \\
\text { area and some } \\
\text { revenue land }\end{array}$ & RF area & $\begin{array}{l}\text { Privately } \\
\text { owned and } \\
\text { RF area }\end{array}$ & RF area & $\begin{array}{l}\text { Radhangari } \\
\text { WLS }\end{array}$ & $\begin{array}{l}\text { Mostly Private } \\
\text { and some } \\
\text { RF area }\end{array}$ \\
\hline $\begin{array}{l}\text { Status of } \\
\text { Mining }\end{array}$ & $\begin{array}{l}\text { Most area } \\
\text { unmined } \\
\text { Portion of } \\
\text { revenue land } \\
\text { is being mined }\end{array}$ & unmined & $\begin{array}{l}\text { Mined with } \\
\text { restoration on } \\
\text { part of the site }\end{array}$ & $\begin{array}{l}\text { Mined with } \\
\text { restoration on } \\
\text { part of the site }\end{array}$ & $\begin{array}{l}\text { Mining } \\
\text { stopped }\end{array}$ & $\begin{array}{l}\text { Mining yet to } \\
\text { start }\end{array}$ \\
\hline $\begin{array}{l}\text { Micro- } \\
\text { habitats }\end{array}$ & $\begin{array}{l}\text { All micro- } \\
\text { habitats seen }\end{array}$ & $\begin{array}{l}\text { All micro- } \\
\text { habitats seen }\end{array}$ & $\begin{array}{l}\text { Restored forest } \\
\text { and EFV }\end{array}$ & $\begin{array}{l}\text { Restored } \\
\text { forest and } \\
\text { EFV }\end{array}$ & $\begin{array}{l}\text { All micro- } \\
\text { habitats seen }\end{array}$ & $\begin{array}{l}\text { All micro- } \\
\text { habitats seen }\end{array}$ \\
\hline
\end{tabular}




\section{Table 2 : Ecological functions of microhabitats}

\author{
Habitat \\ Biological Soil \\ Crust (BSC) \\ composed of \\ cyanobacteria, \\ cynolichens,
}

Boulders

Crevices

Pools

\section{Ecological Functions}

- Breaking down the ferricrete surface, producing biological and mineral detritus, a soil precursor (Porembski et al 2000; Escolar et al 2012,), Enchytraeid worms add considerably to the detrital component of soil precursors (Vaçulik et al 2004)

- Carbon and nitrogen cycling

- Niche creation for higher plants (ex. Murdannia semiteres a thin layer of humus specialist) (Watve 2013)

- Food source for amphibian larvae (Gaitonde and Giri 2014).

- Changing thermal capacity of rock by modifying reflectance

- Moss cushions facilitate vascular plant colonization (Sand-Jensen and Hammer, 2012)

- Refugia for invertebrates (Araneae, Chilopoda, Diplopoda, Scorpiones,).

- Refugia for amphibians and reptiles (Lewis et al in press; Thorpe et al in press; Goldsbrough et al 2003) and for Synbranchoid eels.

- Refugia for novel amphibian species (Giri and Bauer 2008).

- Breeding sites for reptiles, egg deposition beneath loose rocks has been recorded (Pryce et al in press). Micro-pools on large rocks are utilised by specialised anura for egg deposition and larval development e.g. Xanthophryne tigerina (Giri and Bauer 2008).

- Elevated calling points for male amphibians, basking sites for squamata.

- Cheilanthes sp. (Silver fern) and other perennials such as Hoya sp., Dendrobium sp., Eria sp. establish on semi buried rocks.

- Refugia for amphibians, reptiles, desiccation tolerant plants species.

- Establishment of plants less tolerant to desiccation (Porembski et al., 2000). refugia for reptiles (Michael et al., 2010).

- Vernal pools are recognised internationally as a rare habitat and worthy of preservation (Yee 2015).

- Refugia for tadpoles

- Breeding resources for a wide range of invertebrate families including Coleoptera, Hemiptera, Odonata, Nepidae amongst them.

- Sites for brachiopod crustaceans, at least three orders are recognised from ferricretes (Padhye et al 2015)., synbranchoid eels and other fish 